\title{
AFRICAN SWINE FEVER IN POLAND - PREVALENCE, PATHWAYS AND POTENTIAL SPREAD AND REDUCTION POSSIBILITIES
}

\author{
FLIS, M. ${ }^{1}-$ PIÓRKOWSKI, J. ${ }^{2 *}$ \\ ${ }^{I}$ Department of Animal Ethology and Wildife Management, Faculty of Animal Sciences and \\ Bioeconomy, University of Life Sciences in Lublin, ul. Akademicka 13, 20-950 Lublin, Poland
} (ORCID 0000-0001-7429-3158)

${ }^{2}$ Sub-Department of Pathomorphology and Forensic Medicine, Department and Clinic of Animal Internal Diseases, Faculty of Veterinary Medicine, University of Life Sciences in Lublin, ul. Glęboka 30, 20-612 Lublin, Poland

(ORCID 0000-0002-2262-5023)

*Corresponding author e-mail: jacek.piorkowski@up.lublin.pl

(Received 14 ${ }^{\text {th }}$ May 2020; accepted $29^{\text {th }}$ Jul 2020)

\begin{abstract}
The paper presents the epizootic situation of African swine fever in Polish territory from the official confirmation of the first case to the end of 2019. In Poland, there is a genotype II of the virus, the transmission of which is associated with its appearance in Georgia in 2007, followed by its spread to the northwest and subsequent appearance in European countries. During the virus period, an annual increase in the number of cases found in feral domestic pigs and outbreaks in pigs was observed. It was not until 2019, when 2,477 cases were diagnosed, that the virus prevalence stabilized in wild boars and the number of outbreaks in pigs more than doubled compared to 2018. Depopulation of boars carried out during this period, indicated as the primary source of danger, did not bring the expected results. Administrative preventive measures have also failed. The current epizootic situation as well as the appearance of the virus even in places more than $300 \mathrm{~km}$ away from its earlier statements is a confirmation that wild boars are not the basic vector in the spread of ASFV. At the same time, during the disease occurrence, in samples of wild boars shot from regions where the virus appeared, the presence of antibodies increased in the following years. Seropositivity of wild boars indicates the initial phase of viral endemicity in these regions. This creates another epizootic threat, as these animals may become asymptomatic carriers that may infect other individuals in the wild. In the current situation, it seems necessary to develop clear biosecurity principles for pig farms. These principles should also cover all individuals who may become viral mechanical vectors in the environment. Enforcing compliance with biosecurity rules developed in all areas of activity related to pigs and wild boars should be a priority in limiting the spread of ASFV and its possible eradication in Poland.
\end{abstract}

Keywords: wild boar, domestic pig, virus, prevention, biosecurity

\section{Introduction}

The African swine fever virus (ASFV) is a DNA virus that belongs to the Asfavirus species of the family Asfarviridae. It causes acute viral haemorrhagic disease of pigs and wild boars, usually ending in death, therefore it poses a serious threat to pig production all over the world. Its properties provide it with very high resistance to inactivation by physical and chemical agents, which means that under optimal conditions it can be pathogenic for up to 6 years. The disease is characterized by clinical symptoms and sectional changes similar to the acute form of classical swine fever, in particular high fever, significant splenomegaly, high degree of ecchymosis and up to $100 \%$ mortality. In connection with the ban on the treatment of sick animals and the 
lack of vaccines against ASF, the disease is only combated by administrative methods, by killing infected herds and introducing strict biosecurity rules and by limiting, by shooting, the wild boar population as the primary virus reservoir in the natural environment (Markowska-Daniel and Pejsak, 2014; Pejsak and Truszczyński, 2017b; Fila and Woźniakowski, 2020).

The African swine fever virus in Poland was first found on February 14, 2014, based on samples from a wild boar that was found dead in the Sokole County, about $1 \mathrm{~km}$ from the border with Belarus. This case was confirmed by the European Reference Laboratory (EURL) for ASF in Valdeolmos, Spain, on February 18, 2014. On February 17, 2014, a second fallen boar was found near the border with Belarus (Pejsak et al., 2014a). In the following months of 2014, further cases of the virus were confirmed. They occurred only in the border belt of the Podlaskie Voivodeship reaching up to $10 \mathrm{~km}$ inland, along a length of about $50 \mathrm{~km}$ along the border with Belarus (Flis and Nestorowicz, 2019; Woźniakowski et al., 2016). The conducted phylogenetic analyzes showed that in all cases the virus was found in genotype II, i.e. identical as in other Eastern European countries, and showed $99.95 \%$ identity of nucleotides with the Georgia 2007/1 strain (Mazur-Panasiuk et al., 2019a; Śmietanka et al., 2016). Genotype II has also been confirmed by ASFV (African swine fever virus) studies conducted in Belgium in 2018. However, the entire genome sequence of ASFV Belgium 2018/1 showed 15 differences for overall sequence identity at the nucleotide level. A comparison of all available sequences of the entire genome of the virus occurring in Eastern European countries as well as in ASFV in China indicates that these genomes are almost identical with a probability of $99.9 \%$ (Forth et al., 2019; Gilliaux et al., 2019). These data confirm previous reports on the possible direction of virus transmission to Eastern European countries through Georgia and the Caucasus since 2007 and further towards north-eastern Europe (Flis and Nestorowicz, 2019; Markowska-Daniel and Pejsak, 2014; Pejsak et al., 2014a, b; Pejsak and Piekut, 2018).

Since the appearance of the first cases of virus occurrence, the Polish authorities together with veterinary services have undertaken a number of administrative activities introducing further provisions and guidelines to contribute to limiting the possibility of its transmission to new areas (Flis, 2019). This was mainly due to the lack of experience in the scope of the possibility of the virus spreading and the role of wild boars in its transmission to new areas, with varying levels of density of this species and the impact of hunting pressure. Therefore, initially two main hypotheses were adopted. The first of them said that the disease would rapidly spread westwards, while the second indicated the possibility of very rapid extinction of the disease due to the high virulence of the virus, which will naturally lead to depopulation of wild boars. It soon turned out that these hypotheses in Poland's environmental and social conditions did not work. Therefore, actions were taken to exterminate wild boars by hunting. It was related to the fact that the wild boar was indicated as the basic vector of virus spread to new areas (Flis and Kołodziejski, 2019; Flis, 2020; Pejsak et al., 2018b; Probst et al., 2017).

Undoubtedly, in Poland's environmental conditions, wild boars constitute the primary reservoir of the virus (Flis and Nestorowicz, 2019; Flis and Kołodziejski, 2019; Pejsak et al., 2018b). Therefore, high population density rates have an impact on the increase in the possibility of the virus traveling in the environment, where it spreads in a diffusive manner, i.e. without human intervention (Śmietanka et al., 2016; Pejsak and Truszczyński, 2017b). In addition, in border zones, the spread may also be partly dependent on the occurrence of the virus in neighboring countries (Flis and 
Nestorowicz, 2019; Flis, 2020; Markowska-Daniel et al., 2011). Assessment of the geographical pattern of virus spread indicates that wild boars can be a virus vector to areas not far away from the sites of its previous findings. This is due to the fact that the virus in the natural environment has clear connectivity with habitats, without a tendency to dynamically move over time. In the natural environment, regardless of the season, it spreads with an average pace of 1-2 km per month (Abrahantes et al., 2017; Depner et al., 2016; Podgórski and Śmietanka, 2018).

The aim of the study was to analyze the epizootic situation of African swine fever in Poland in terms of the preventive measures taken so far, including measures related to the depopulation of wild boars and its impact on the spread of the virus from its appearance, i.e. from February 2014 to the end of 2019. The analysis included virus cases found in feral pigs and outbreaks in pigs in individual years of the study period, as well as a geographical model of virus spread and indication of possible vectors related to transmission to diverse environments, including pig-keeping farms, which will allow for the development of further groups of activities preventive measures in the scope of limiting the possibilities of ASFV transmission to new areas.

The presented data include only officially reported cases in which the presence of ASFV has been confirmed in laboratory tests. Certainly, some of the fallen boars are not found and remain in the natural environment, constituting a reservoir for the virus. In addition, there may also be situations where a dead boar is found and the case has not been reported. The number of these wild boars is difficult, and even impossible to determine precisely. Information from conducted search campaigns, during which the boar's dwelling places are meticulously penetrated, indicates that these are not common cases. Thus, the number of such cases does not affect the results presented.

\section{Materials and methods}

\section{Material}

The research material was the data of the Main Veterinary Inspectorate. They concerned officially identified cases of African swine fever virus in feral pigs since 2014, when the virus was first detected until the end of 2019. These data come from monitoring studies from every wild boar shot in the danger area (blue zone), restricted area (red zone) and protection area (yellow zone). These data also include the results of tests for the presence of ASF from every dead boar, regardless of the cause of death from all over Poland. Samples are taken from all wild boars from car collisions. In addition, they are also collected from fallen boars found occasionally, by persons staying in the wild boar's habitat, as well as from those found as part of organized search for fallen animals. Depending on the method of obtaining biological material, different samples are taken. Blood is collected from the boars shot. This is done by hunters or other persons authorized by district veterinarians. On the other hand, if dead pigs are also able to take blood samples, and if the carcasses are already in a state of decay, samples are taken from internal organs, mainly spleen, possibly kidneys or lungs. In cases of highly advanced degradation, samples are taken from the bone marrow.

\section{Analyses}

The collected material was tested on an ongoing basis in the national reference laboratories for ASFV, to which samples collected in the field were delivered. Two 
diagnostic methods are used in these tests. The first of these involves an ELISA test (Enzyme-Linked Immunosorbent Assay) to detect anti-ASFV antibodies. The second study is based on the molecular method of qPCR (real-time PCR - Ingezim PPA COMPAC, Ingenasa, Spain), i.e. a polymerase chain reaction to detect and identify ASFV genetic material. Soft tissues or bone marrow are also examined by real-time PCR. Each positive or doubtful sample in the ELISA was tested by a confirmatory indirect immunoperoxidase (ITP) technique that shows higher sensitivity than the ELISA. This method is recommended by EURL for ASF (CISA-INIA Valdeolmos).

\section{Material development}

On the basis of the obtained data, the dynamics of virus transmission and the geographical pattern of its spatial distribution in individual years were compiled. The prevalence index in wild boars was also calculated. It represented the percentage of positive cases found to the total number of wild boars tested. Also presented are data obtained from the National Veterinary Institute in Pulawy regarding the number of seropositive wild boars, which allowed determining the percentage of such animals in relation to the number of tested animals. Also presented is a geographical model of the possibility of the virus spreading to new areas through environmental vectors such as wild boars and indirect vectors. mechanical, related to multidirectional human activity. An analysis was also made of the dynamics of the number of wild boars in terms of the level of hunting exploitation of the population of this species, which is directly related to the occurrence and spread of the virus in the natural environment and potential possibilities of reaching pig farms. Data on numbers and hunting of wild boars were obtained from the Polish Hunting Association.

\section{Results}

\section{Occurrence of ASF virus in Poland}

In the period from 2014, when the virus was found in Poland for the first time, the number of cases found in wild boars tended to increase (Fig. 1). However, a very dynamic increase of over 9 times occurred in 2017 when 741 cases were found. In the following year, a further more than 3-fold increase in cases was observed, while in 2019 there was a relative stabilization compared to the previous year. Slightly different tendency of outbreaks was observed in pigs. In the first two years, the number of outbreaks was small. There was a dynamic increase in the number of outbreaks in 20162018. In turn, in 2019 there was more than a 2-fold decrease compared to the previous year. The spatial distribution of the virus occurrence in individual years indicates a clear tendency of its spread towards the west and a bit slower, though successive towards the north and south (Fig. 2a-f). In the subsequent years of virus incidence, the number of wild boars covered by the ASF testing increased (Table 1). In 2014, 15,881 samples from wild boars were tested, and in 201977812 samples. In the initial 5 years, the prevalence index increased every year from 0.19 in 2014 to 5.56 in 2018 (Fig. 3). In 2019, despite the largest number of samples tested, this indicator dropped to 3.18.

Almost from the very beginning of the virus in Poland, ASFV antibodies were found during laboratory tests (Table 1). This indicates that these individuals have been in contact with the virus. The first such case was already recorded in December 2014. The percentage of seropositive wild boars increased with the increase in the number of 
samples and the virus cases found. It is difficult to clearly indicate whether these animals had contact with a small dose of the virus and the immune system generated immunoglobulins, which meant that the virus did not lead to death, or whether these individuals contracted the virus. The possibility of acquiring antibodies from the mother in utero or with colostrum is also not fully known, and the results of the study also show their occurrence in young wild boars.

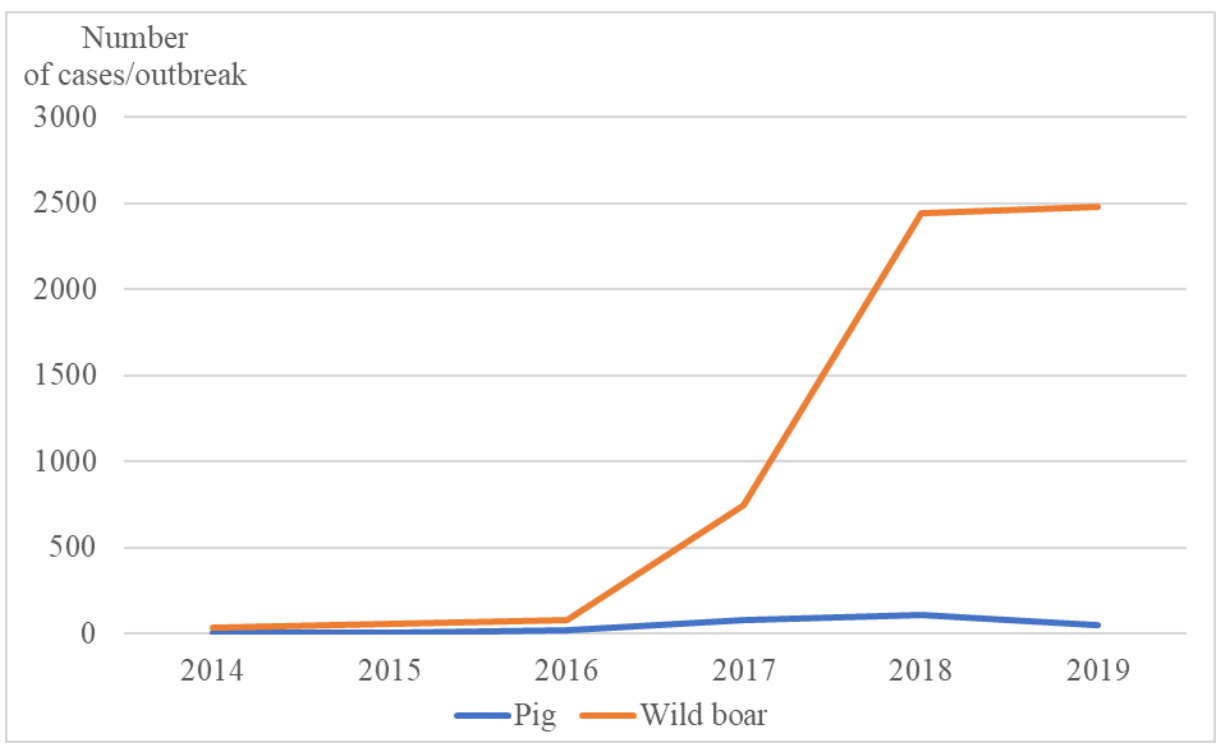

Figure 1. The number of ASF virus outbreaks in pigs and cases found in wild boars in Poland in 2014-2019

Table 1. Presence of antibodies in tested wild boars

\begin{tabular}{c|c|c|c|c|c|c}
\hline \multirow{2}{*}{ Item } & \multicolumn{7}{c}{ Years } & $\mathbf{2 0 1 8}$ & $\mathbf{2 0 1 9}$ \\
\cline { 2 - 7 } & $\mathbf{2 0 1 4}$ & $\mathbf{2 0 1 5}$ & $\mathbf{2 0 1 6}$ & $\mathbf{2 0 1 7}$ & $\mathbf{2 0 1 8}$ \\
\hline Number of wild boars examined & 15881 & 13356 & 14965 & 24698 & 43911 & 77812 \\
\hline Number of cases & 30 & 53 & 80 & 741 & 2443 & 2477 \\
\hline $\begin{array}{c}\text { Number of wild boars tested for } \\
\text { antibodies* }\end{array}$ & 4218 & 7694 & 8575 & 16303 & 35007 & 30395 \\
\hline $\begin{array}{c}\text { Number of wild boars seropositive* } \\
\text { Percentage of wild boars with } \\
\text { antibodies compared to tested }\end{array}$ & 1 & 8 & 18 & 95 & 274 & 391 \\
\hline
\end{tabular}

*Data from the State Veterinary Institute in Pulawy

\section{Routes and directions of ASFV spread in wild boar}

From the very beginning of the appearance of the virus in Poland, it spread mainly in the natural environment, which was confirmed by subsequent cases of the virus in boars in this region. The main areas were related to the border belt, where the virus spread to subsequent areas along the eastern border of Poland and successively occupied further areas to the west. In this case, it is undeniable that the main vector of the virus was certainly infected with wild boars or their corpses. In border areas, it could certainly also be cross-border migrations of infected wild boars (Fig. 4). 

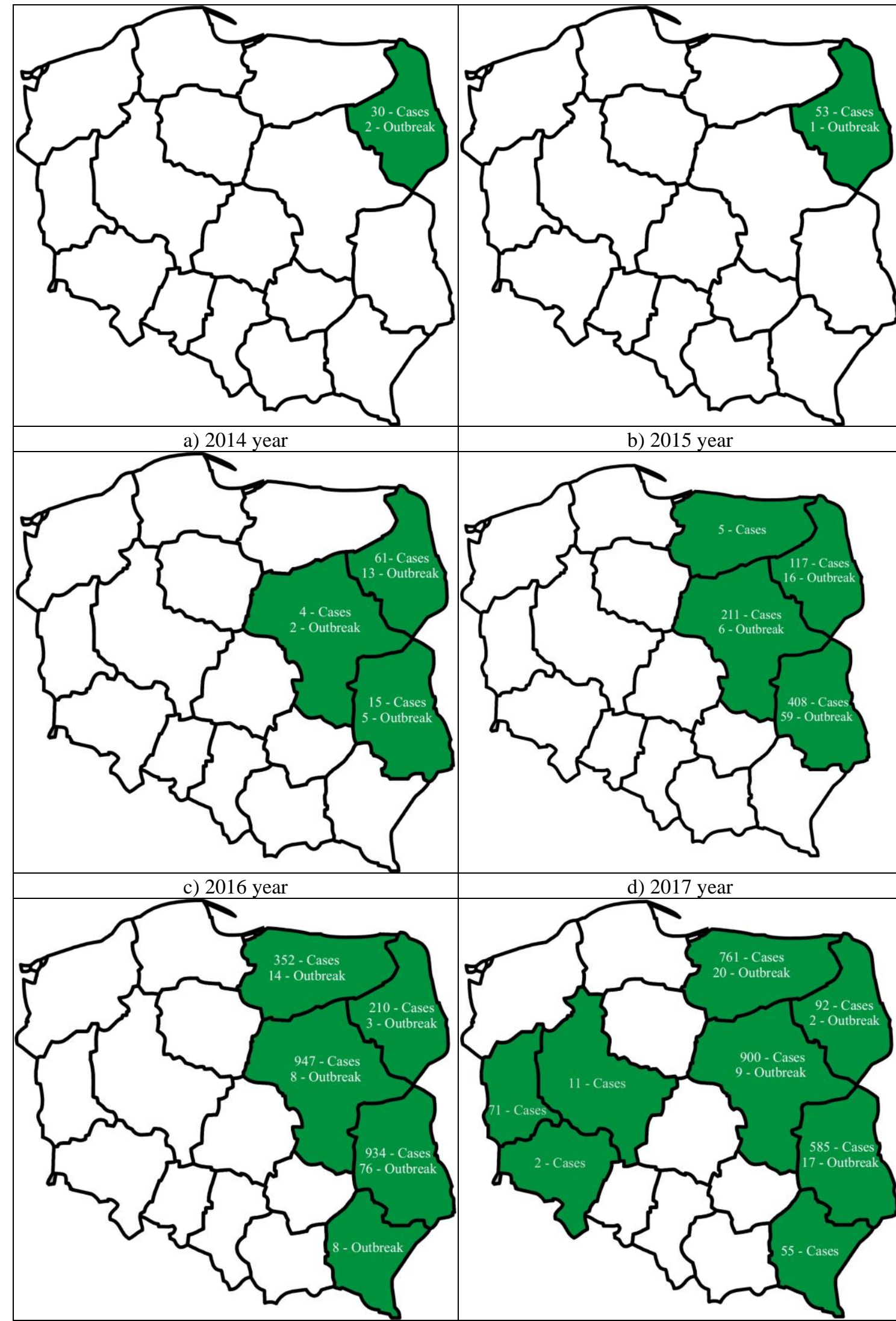

e) 2018 year

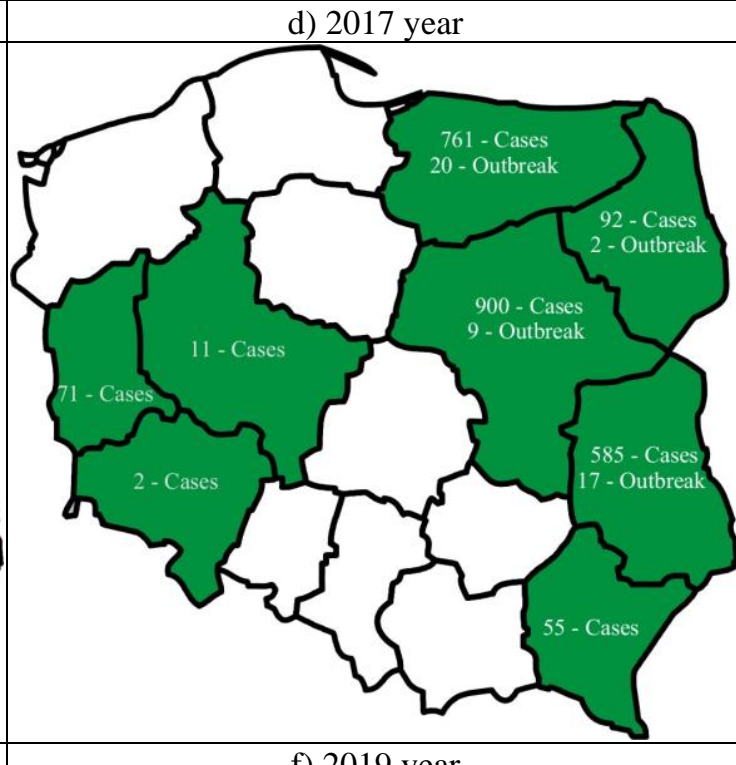

Figure 2. (a-f) Geographical pattern of ASF virus in Poland in the years 2014-2019 


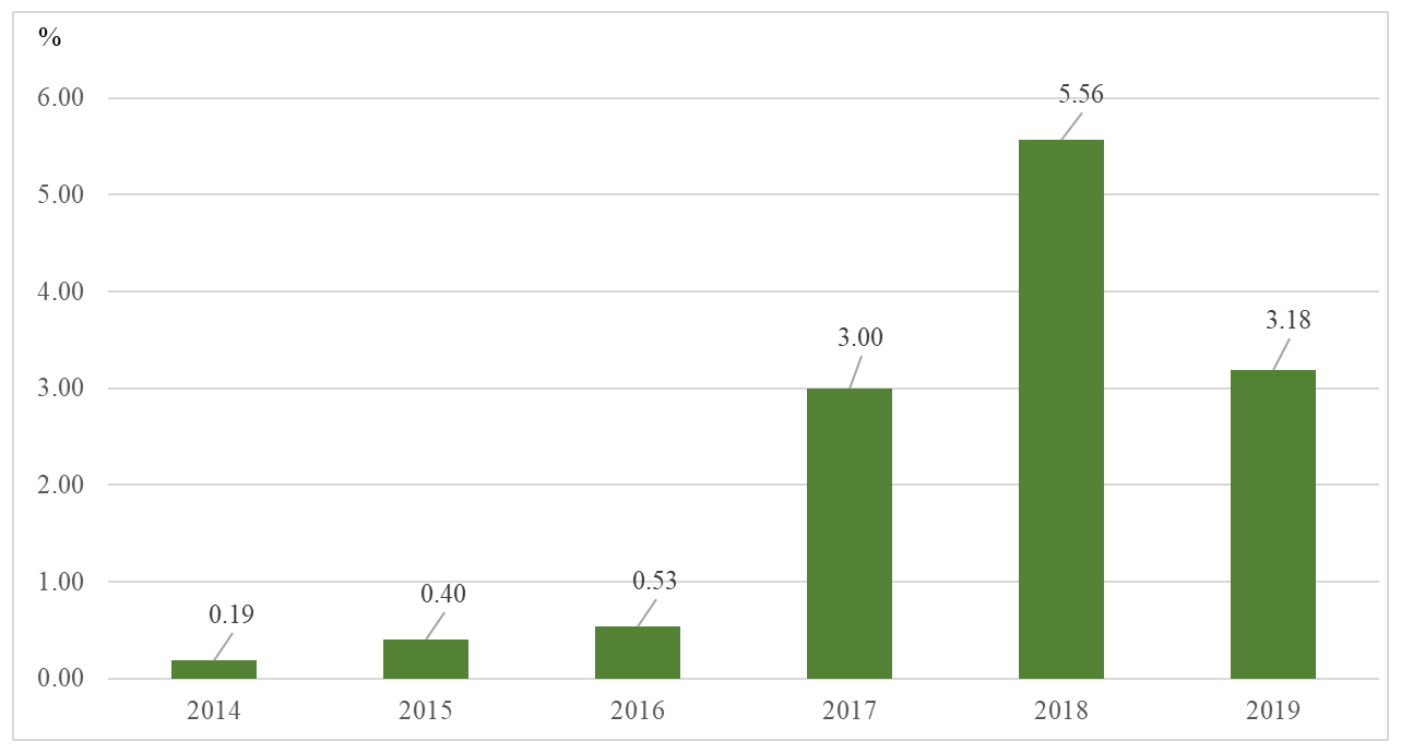

Figure 3. Prevalence index in wild boars in Poland in 2014-2019

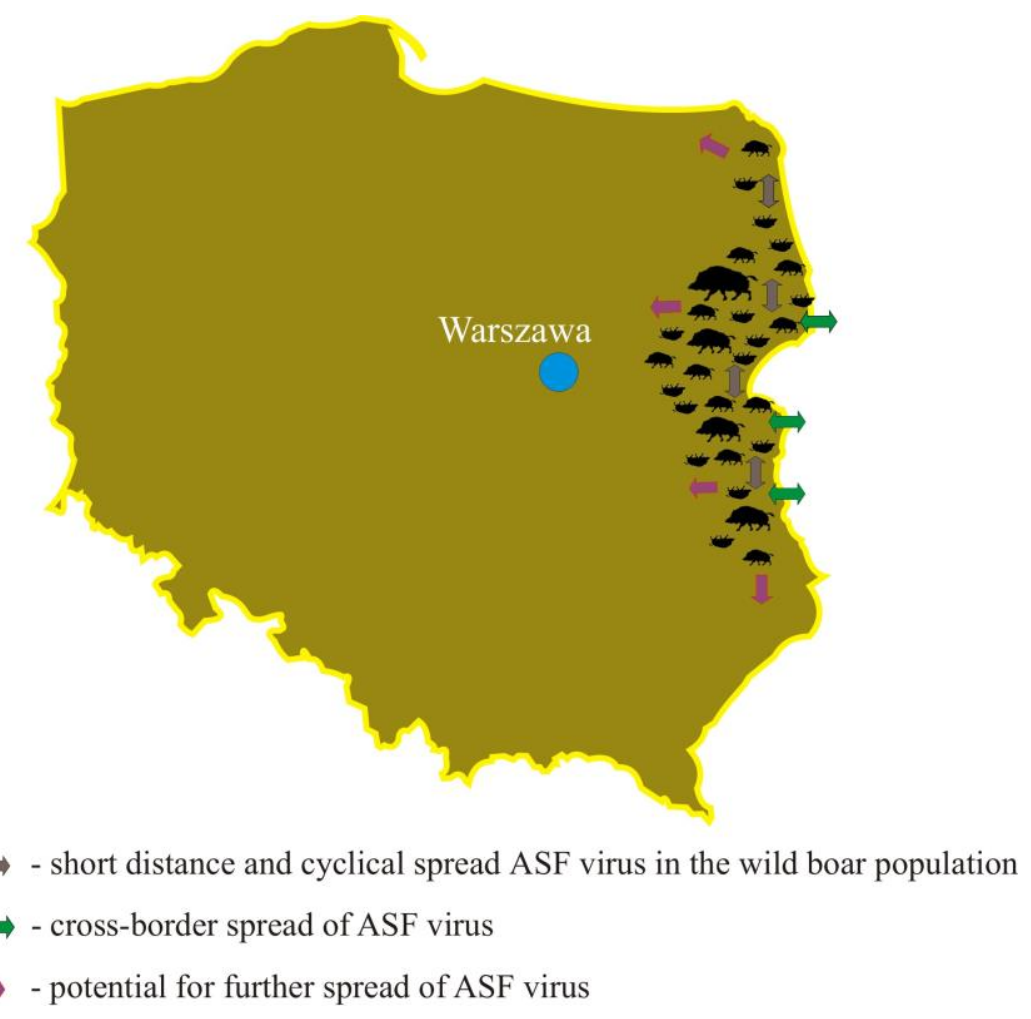

Figure 4. Geographic pattern of short-distance ASF virus movement in determined wild boars by environmental factors in Poland in the years 2014-2016

However, starting from 2017, there was an unexpected spread of the virus to new areas, quite distant from the sites of earlier statements. The first of them were around Warsaw, and the next regions of northern Poland, just off the Kaliningrad region. Crossborder migration of feral pigs was indicated as the main reason for the emergence of a new region of virus occurrence, just off the northern border, quite far away from its 
current sites. However, the appearance of the virus near Warsaw cannot be equated with any wild boar migration. At most, two hypotheses were mentioned. The first of these was about transporting the unexplored carcass of a wild boar from areas where the virus had not yet been officially diagnosed and could have been present in the environment and the boar was infected. The second, more likely, said that unconscious human activity and the introduction of the virus into new areas contributed to this by failing to follow biosecurity principles when moving from areas where the virus was already present in the natural environment (Fig. 5).

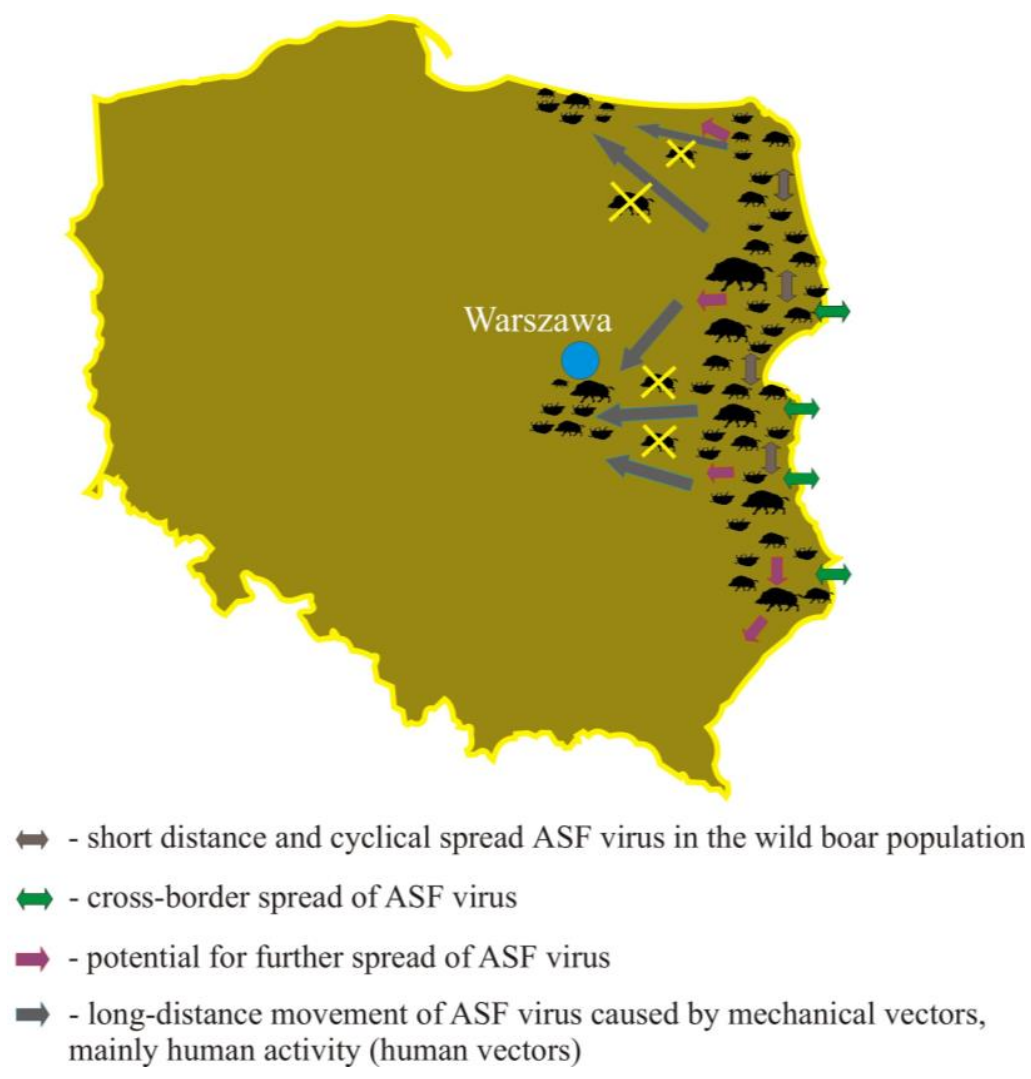

Figure 5. Geographic pattern of short and long-distance ASF virus movement in determined wild boars by environmental factors and human vectors in Poland in the year 2017

Another case of virus transmission to new, very remote areas was recorded in Poland in 2019, when the virus was diagnosed in a dead boar, near the town of Slawa on Tarnowskie Lake in southwestern Poland (Fig. 6). The determined distance in a straight line from the most westerly case in places of earlier virus occurrence in boars and pigs in the eastern and central part of Poland was slightly over $300 \mathrm{~km}$. Thus, there is no epidemiological and, above all, geographical link with existing virus cases. This is another confirmation that mechanical vectors, mainly humans, play a key role in virus transmission.

\section{Routes of ASF virus entry into pig-keeping farms}

In Poland, 246 outbreaks in pigs have been reported since the appearance of the ASF virus. In the initial period, the outbreaks were few and were found in small farms, 
holding a few pigs each. This was mainly due to the way pigs were kept and fed, and thus the lack of any biosecurity. Along with the extension of the range of occurrence, outbreaks also appeared on larger farms. The successively increasing losses reached hundreds or even thousands of pigs, which were slaughtered and disposed of. In total, during the period 2014-2019, 67415 pigs were slaughtered and disposed of, which generated huge economic losses. Regardless of the type of farms in which there were outbreaks, although the paths of virus penetration were not always recognized and described in detail, in most cases they were associated with a mechanical vector associated with human activity. There is no reason to conclude, which is also logical for the wild boar to drag the virus into the farm, including the piggeries. In addition, the aspect related to virus neutralization in facilities where sick pigs were kept was not fully understood. Thus, in areas where the virus was present, the infection could have a twoway nature, and the virus could circulate between farms and the environment.

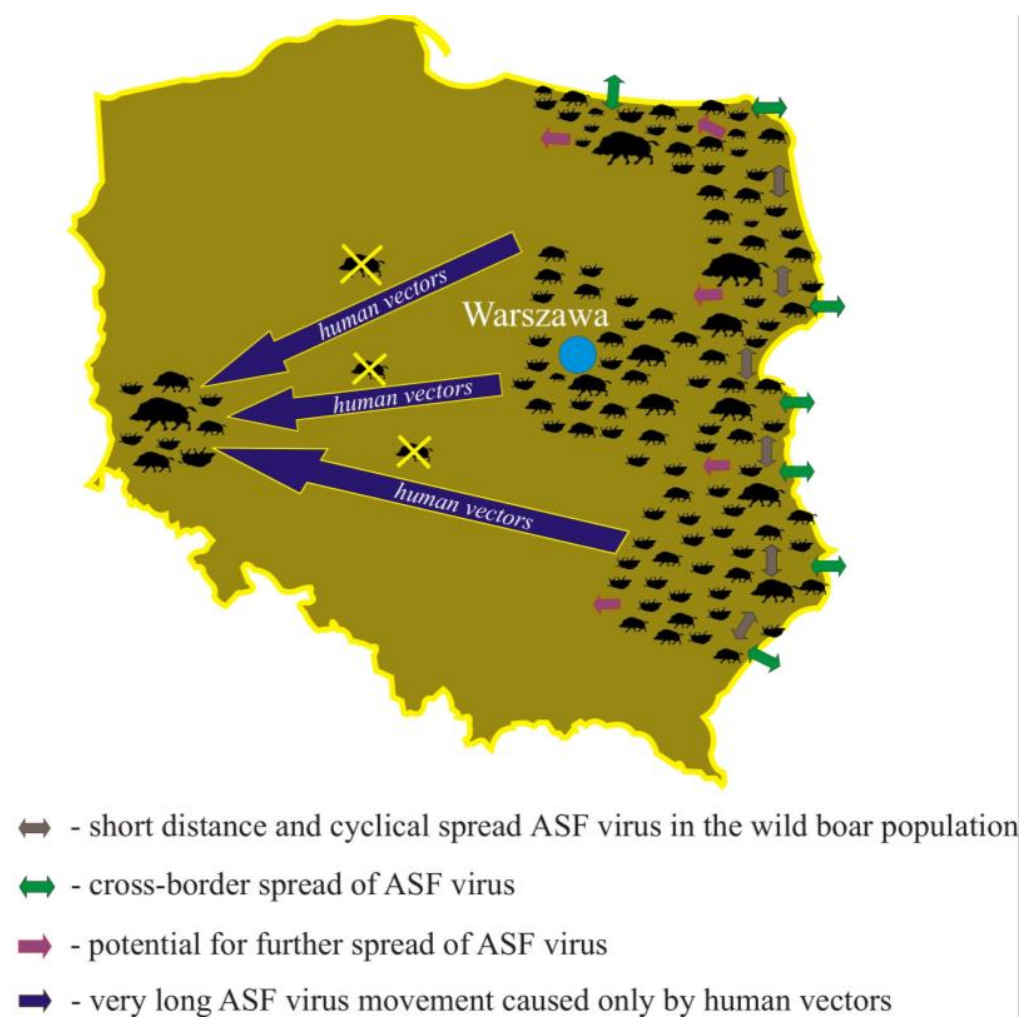

Figure 6. Geographic pattern of short and very long-distance ASF virus movement in determined wild boars by environmental factors and human vectors in Poland in the year 2019

\section{Preventive actions}

Even before the virus was officially confirmed in Poland, the first administrative and preventive initiatives were undertaken. In January 2014, guidelines were issued regarding the rules of conduct aimed at preventing the virus from entering the territory of the Republic of Poland. However, less than a month after this, the virus was officially confirmed and these guidelines became pointless. The next package of rules of conduct was released in March 2014 and contained a number of guidelines for pig farmers. It included guidelines on farm biosecurity rules and the possibilities for pigs to move. At that time, the wild boar was defined as the main virus vector in terms of its 
transferability to pig-keeping farms. It is worth emphasizing that these guidelines in the initial period of implementation introduced a total ban on hunting boars.

In the following years, further programs were introduced to detect early infections by the African swine fever virus and to increase knowledge about this disease. In these programs, the approach to wild boars changed radically, and the guidelines contained in them pointed to the need for depopulation of this species. What is more, in addition to hunting, compulsory (sanitary) shots were implemented based on the decisions of the Veterinary Inspection, as well as cash bonuses for shots carried out. These guidelines also introduced the mandatory search for fallen wild boars and the rules of conduct of hunters during hunting and after shooting in the field of biosecurity. Although they introduced clear guidelines for the biosecurity of pig farms, in many cases they were not followed, as confirmed by the inspections carried out. Such activities contributed to reducing the number of wild boar populations, which were indicated as the main source of virus transmission to farms. Further guidelines on the depopulation of wild boars, due to massive hunting conducted since 2017, caused a drastic decrease in the number of wild boars (Fig. 7). Arguments regarding wild boars as the primary source of threat to pig farming were not entirely correct, as the depopulation carried out in no way affected the number of cases and the possibility of the virus spreading to new areas as well as the number of outbreaks on pigs on farms.

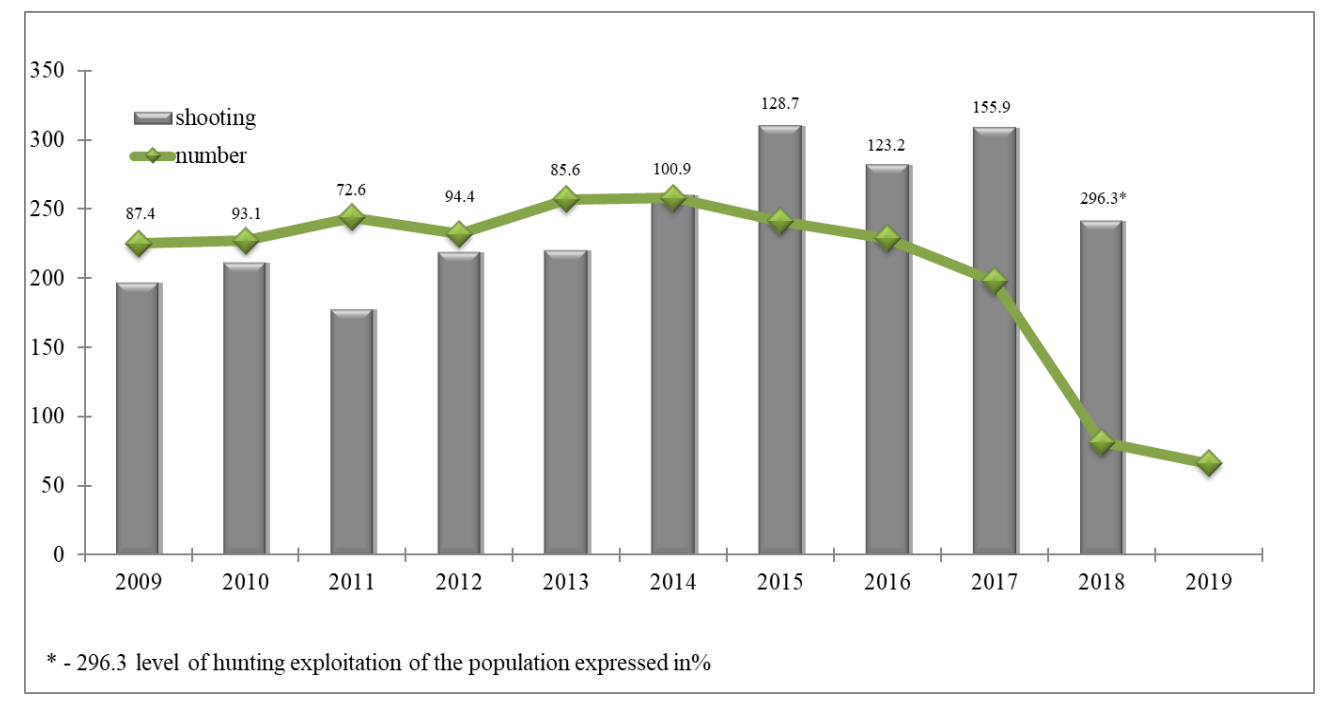

Figure 7. Numbers and hunting of wild boars (thousand individuals) in districts leased by the Polish Hunting Association in the last decade

\section{Discussion}

African swine fever as an infectious disease, causing almost $100 \%$ mortality in porcine animals (Suidae), poses a serious threat to the European and global pig market. Starting from 2007, he expanded the range of his presence to include Eastern European countries, and in subsequent years his successive expansion towards Western Europe occurs. Due to the fact that currently no vaccine is available, the only way to combat and thus limit further spread is to follow the principles of biosecurity (MarkowskaDaniel and Pejsak, 2014; Pejsak et al., 2018b; Mazur-Panasiuk et al., 2019b).

The presented epizootic situation in Poland indicates that the boar remains the primary reservoir of the virus in the natural environment, but it is not the main vector of 
its spread. At the same time, all administrative measures taken so far to combat and limit the transmission to new areas have not yielded any results (Flis, 2019; Pejsak et al., 2018b). It was determined by the speed of virus transmission in the natural environment. Research in this area indicates that the virus, regardless of the season of the year and environmental conditions, spreads at an average rate of about 1-2 km per month (Abrahantes et al., 2017; Depner et al., 2016; Podgórski and Śmietanka, 2018). This is also confirmed by the results of Russian studies, which highlighted the lack of dependence of the epidemic in pigs and wild boars, as they were independent of each other. At the same time, the authors of these studies indicate a high probability of infecting wild boars through various by-products associated with breeding and keeping pigs (Vergne et al., 2017).

The increase in the spatial development of the virus in Poland in the years 2014-2019 has shown that there are certainly different directions of infection in both wild boars and pigs. The presented results indicate almost unambiguously that the key role is played by wild boars, however, other transmission routes should not be underestimated, especially to pig-keeping farms, including a number of factors referred to as mechanical vectors. Some tick species from the Ornithodorus genus may play an important role in transmitting the pathogen. Although in European conditions these ticks do not occur in the natural environment, this route of transmission should not be underestimated, even by importing accompanying animals susceptible to this group of arachnids. As a rule, they are asymptomatic carriers of the virus, however, ASFV can replicate in their body and survive up to five years, being a potential source of infection for a sensitive species (Arias et al., 2018; De Carvalho Ferreira et al., 2014; Galindo and Alonso, 2017; Fila and Woźniakowski, 2020; Plowright et al., 1969). Some species of flies may also be involved in the transmission of the virus, which may be mechanical vectors of the virus, transferring it within $24 \mathrm{~h}$ through blood infected with the virus, as well as infection may occur orally by ingestion by animals infected with the virus (Galindo and Alonso, 2017; Baldacchino et al., 2013; Mellor et al., 1987; Olesen et al., 2018b). The possibility of transmission of the virus through mammals and birds of prey, as well as scavengers, which can be mechanical vectors of the spread of the virus is not fully understood. German studies conducted on carcasses of dead boars have shown that both birds and mammals, including domestic dogs, have had contact with carrion, and thus these animals may be mechanical viral vectors (Probst et al., 2017). In the case of virus transmission to pig-keeping farms, a key role may also be played by feed contaminated with pathogen, coming from fields and meadows, not quarantined (Guinat et al., 2016; Thomson, 1985).

The development of the epizootic situation in Poland during the 6 years of the presence of the ASF virus shows that the virus occurs in the natural environment, where its only reservoir is wild, but the basic vector of virus spread is the human factor. This is confirmed by its transmission to the areas around Warsaw (Mazur-Panasiuk and Woźniakowski, 2019; Pejsak et al., 2018a), or the appearance in Western Poland at a distance of $300 \mathrm{~km}$, from earlier places of its finding (Flis, 2020). Also cases of its appearance in other European countries (Czech Republic, Belgium) distant hundreds of kilometers from places of its occurrence in this period (Forth et al., 2019; Gilliaux et al., 2019; Flis and Kołodziejski, 2019). Confirmation of the thesis that mechanical vectors play a key role in virus transmission in Poland are data from other European countries. In the case of the Czech Republic, the virus vector was workers from Eastern Europe, 
while the Belgian case was associated with the transport of carcass of an infected wild boar by hunters from Lithuania (Flis and Nestorowicz, 2019).

There is also no doubt that wild boars remain the primary reservoir of the virus. However, taking into account the behavior of this species and the fact of the emergence of new cases of the virus in areas quite distant by places of earlier statements, it is impossible to agree with the thesis that it is boars that are the main factor associated with the spread of the virus to new areas (Flis, 2020; Flis and Nestorowicz, 2019; Keuling et al., 2009; Schultz et al., 2019b). Therefore, one of the priority tasks in the field of prevention in the spread of the virus is to comply with the principles of biosecurity resulting from the introduced veterinary regimes (Flis and Kołodziejski, 2019; Pejsak et al., 2018a). This is confirmed by the analysis of the spatial spread of the virus in Poland. They point to the need for more effective prevention and control measures in areas of permanent virus prevalence during the epidemic season, in pigs in summer and in wild boars in winter. It is also necessary to permanently assess the level of risk of spreading the virus (Lu et al., 2019).

In ASFV transmission, some role may be played by wild boars, which have been in contact with the virus and have infected it. The number of such animals during the period of virus occurrence in Poland is gradually increasing, and this is confirmed by the presence of antibodies in the tissues of these animals. These animals mainly come from areas where the virus has been around for a long time. Thus, they can be asymptomatic carriers of the virus. However, there is no evidence that every seropositive animal is a long-term virus carrier (Ståhl et al., 2019). A similar trend in the growing number of seropositive wild boars occurs in Estonia, where their incidence is definitely higher in those regions where the virus was the first to appear (Schulz et al., 2019a). Research results from Poland and the Baltic States show that there is a positive correlation between the time of infection and the occurrence of seropositive individuals (Martínez-Avilés et al., 2020). Such a course of the disease may be the beginning of its endemic in these regions (Schulz et al., 2019a). Also studies in pigs who have recovered from an acute ASF infection in the Netherlands have shown that these pigs can transmit the disease to other individuals through direct contact (Eblé et al., 2019). Research on the possibility of virus transmission through the environment in which virus infected pigs euthanized, conducted in Poland, Podlasie, showed that the introduction of healthy pigs to the same pens the next day led to the development of the disease in one week. Only at least 3 days quarantine eliminated virus transmission to subsequent individuals through a contaminated environment (Olesen et al., 2018a). Thus, in the current conditions of multi-directional possibilities of virus transmission to new areas, both in Poland and other European countries, farms keeping pigs should be almost isolated from the outside world. This is due to the fact that the virus is introduced to farms via indirect transmission paths, with a lack of biological security (Nurmoja et al., 2018; Pejsak and Truszczyński, 2018).

In the scope of preventive actions, elements related to the utilization of all remains of dead animals by specialized rendering companies with the principles of biosecurity are extremely important. This applies to both pigs and wild boars or their remains remaining in the wild. Therefore, one of the most important preventive elements in wild boars should be searching for dead animals, their utilization and proper disinfection of places where carrion was found (Flis, 2020; Flis and Kołodziejski, 2019; Halasa et al., 2016; Pejsak and Truszczyński, 2017a; Pejsak and Woźniakowski, 2017). 


\section{Conclusion}

The presented data regarding the epizootic situation associated with the occurrence of the ASFV virus on the territory of Poland clearly indicate that despite the administrative and preventive measures taken in the field of virus eradication, they did not bring the expected results. During the period of six years, the virus spread to almost half of Poland's territory. Analysis of the geographical pattern of virus spread indicates that mechanical vectors, and mainly multidirectional human activity, play a key role in its transmission to new areas. Previous efforts in the field of depopulation of feral pigs considered both as a reservoir and as a virus vector have failed. Although the density of wild boar population is an important element in virus transmission within neighboring groups, it does not play a key role in its transmission to new, quite often remote areas from the sites of previous statements. Wild boar is also not directly related to the transmission of the virus to pig farms. Nevertheless, in Polish conditions, regardless of population density, wild boars remain the only reservoir of the virus in the natural environment.

Due to describing the next possibilities of virus transmission to new areas through the so-called mechanical vectors should be focused on searching for dead animals, as well as their remains at various stages of decomposition, as well as their removal from the environment and thorough disinfection of their locations. All such activities reduce the germ reservoir in the environment, and thus the possibility of its further transmission. The knowledge and observance of biosecurity rules by pig farmers, as well as hunters and other people staying in places of potential occurrence of boars or their periodic concentration should be absolutely binding. The possibility of limiting the use of the environment should also be considered, especially in places susceptible to the occurrence of wild boars. The effect of this initiative should be to limit further possibilities of spreading the virus among wild boars and result in limiting its further transmission to new areas. New fast and comprehensive solutions should also be sought to combat the virus, especially in areas where it appears for the first time. The Czech case is the best confirmation that decisive action may limit transmission possibilities and even lead to virus eradication.

It is also necessary to conduct further research on the possibilities of virus transmission to new areas through diverse vectors, both environmental and those associated with human activities. These studies should focus on determining the magnitude of the impact of human-dependent factors in the spread of the virus, and on this basis indicate the possibility of developing methods to minimize anthropogenic factors that have a significant impact on further transmission of the virus. The research aimed at determining the role of wild boars in the spread of the virus, as well as determining the level of density of the wild boar population guaranteeing the inhibition of virus transmission from the environment to farms keeping pigs are also significant.

Acknowledgments. The authors thank the State Veterinary Institute in Pulawy for sharing some data.

Conflicts of interests. The sponsors had no role in the design, execution, interpretation, or writing of the study.

\section{REFERENCES}

[1] Abrahantes, J. C., Gogin, A., Richardson, J., Gervelmeyer, A. (2017): Epidemiological analyses on African swine fever in the Baltic countries and Poland. - European Food Safety Authority Journal 15. DOI: 10.2903/j.efsa.2017.4732. 
[2] Arias, M., Jurado, C., Gallardo, C., Fernández-Pinero, J., Sánchez-Vizcaíno, J. M. (2018): Gaps in African swine fever: analysis and priorities. - Transboundary Emerging Diseases 65: 235-247.

[3] Baldacchino, F., Muenworn, V., Desquesnes, M., Desoli, F., Charoenviriyaphap, T., Duvallet, G. (2013): Transmission of pathogens by Stomoxys flies (Diptera, Muscidae): a review. - Parasite 20: 26. DOI: 10.1051/parasite/2013026.

[4] De Carvalho Ferreira, H. C., Tudela Zúquete, S., Wijnveld, M., Weesendorp, E., Jongejan, F., Stegeman, A., Loeffen, W. L. A. (2014): No evidence of African swine fever virus replication in hard ticks. - Ticks Tick-Borne Diseases 5: 582-589.

[5] Depner, K. R., Blome, S., Staubach, C., Probst, C., Globig, A., Dietze, K., Sauter-Louis, C., Conraths, F. J. (2016): Die Afrikanische Schweinepest - eine Habitatseuche mit häufig niedriger Kontagiosität. - Praktische Tierarzt 96: 536-544.

[6] Eblé, P. L., Hagenaars, T. J., Weesendorp, E., Quak, S., Moonen-Leusen, H. K., Loeffen, W. L. A. (2019): Transmission of African swine fever virus via carrier (survivor) pigs does occur. - $\quad$ Veterinary Microbiology 237: 108345. doi.org/10.1016/j.vetmic.2019.06.018.

[7] Fila, M., Woźniakowski, G. (2020): African swine fever virus - the possible role of flies and other insects in virus transmission. - Journal Veterinary Research 64: 303-310.

[8] Flis, M. (2019): Combating African swine fever by administrative means. - Życie Weterynaryjne 94: 419-422.

[9] Flis, M. (2020): Possibilities of spreading African swine fever and its occurrence in Poland in 2019. - Życie Weterynaryjne 95: 86-88.

[10] Flis, M., Kołodziejski, A. (2019): African swine fever - facts, myths, reality. - Życie Weterynaryjne 94: 199-202.

[11] Flis, M., Nestorowicz, J. (2019): African swine fever in Poland - routes and directions of spread, with particular reference to Lublin Voivodship. - Życie Weterynaryjne 94: 574577.

[12] Forth, J. H., Tignon, M., Cay, A. B., Forth, L. F., Höper, D., Blome, S., Beer, M. (2019): Comparative analysis of whole-genome sequence of African swine fever virus Belgium 2018/1. - Emerging Infectious Diseases 25: 1249-1252.

[13] Galindo, I., Alonso, C. (2017): African swine fever virus: a review. - Viruses 9: 103. DOI: $10.3390 / \mathrm{v} 9050103$.

[14] Gilliaux, G., Garigliany, M., Licoppe, A., Paternostre, J., Lesenfants, C., Linden, A., Desmecht, D. (2019): Newly emerged Africa swine fever virus strain Belgium/Etalle/wb/2018. Complete genomic sequence and comparative analysis with reference p72 genotype II strains. - Transbound Emerging Diseases 66: 2566-2591.

[15] Guinat, C., Gogin, A., Blome, S., Keil, G., Pollin, R., Pfeiffer, D. U., Dixon, L. (2016): Transmission routes of African swine fever virus to domestic pigs: current knowledge and future research directions. - Veterinary Record 178: 262-267. DOI: $10.1136 /$ vr. 103593.

[16] Halasa, T., Botner, A., Mortensen, S., Christensen, H., Toft, N., Boklund, A. (2016): Control of African swine fever epidemics in industrialized swine populations. Veterinary Microbiology 197: 142-150.

[17] Keuling, O., Stier, N., Roth, M. (2009): Commuting, shifting or remaining? Different spatial utilisation patterns of wild boar Sus scrofa L. in forest and field crops during summer. - Mammalian Biology 74: 145-152.

[18] Lu, Y., Deng, X., Chen, J., Wang, J., Chen, Q., Niu, B. (2019): Risk analysis of African swine fever in Poland based on spatio-temporal pattern and Latin hypercube sampling, 2014-2017. - BMC Veterinary Research 15: 160. doi.org/10.1186/s12917-019-1903-z.

[19] Markowska-Daniel, I., Pejsak, Z. (2014): African swine fever. - Życie Weterynaryjne 89: 191-196. 
[20] Markowska-Daniel, I., Ziętek-Barszcz, A., Bocian, Ł., Kukier, M., Pejsak, Z. (2011): The risk assessment of the African swine fever transmission from Kaliningrad area to Poland. - Życie Weterynaryjne 86: 427-431.

[21] Martínez-Avilés, M., Iglesias, I., De la Torre, A. (2020): Evolution of the ASF infection stage in wild boar within the EU (2014-2018). - Frontiers Veterinary Science: 7. doi.org/110.3389/fvets.2020.00155.

[22] Mazur-Panasiuk, N., Woźniakowski, G. (2019): The unique genetic variation within the O174L gene of Polish strains of African swine fever virus facilitates tracking virus origin. - Archives Virology 164: 1667-1672.

[23] Mazur-Panasiuk, N., Woźniakowski, G., Niemczuk, K. (2019a): The first complete genomic sequences of African swine fever virus isolated in Poland. - Scientific Report 9: 4556.

[24] Mazur-Panasiuk, N., Żmudzki, J., Woźniakowski, G. (2019b): African swine fever virus perspective in different environmental conditions and the possibility of its indirect transmission. - Journal Veterinary Research 63: 303-310.

[25] Mellor, P. S., Kitching, R. P., Wilkinson, P. J. (1987): Mechanical transmission of capripox virus and African swine fever virus by Stomoxys calcitrans. - Research Veterinary Science 43: 109-112.

[26] Nurmoja, I., Mõtus, K., Kristian, M., Niine, T., Schulz, K., Depner, K., Viltrop, A. (2018): Epidemiological analysis of the 2015-2017 African swine fever outbreaks in Estonia. - Preventive Veterinary Medicine. doi.org/10.1016/j.prevetmed.2018.10.001.

[27] Olesen, A. S., Lohse, L., Boklund, A., Halasa, T., Belsham, G. J., Rasmussen, T. B., Bøtner, A. (2018a): Short time window for transmissibility of African swine fever virus from a contaminated environment. - Transboundary Emerging Diseases 65: 1024-1032. DOI: 10.1111.tbed.12837.

[28] Olesen, A. S., Lohse, L., Hansen, M. F., Boklund, A., Halasa, T., Belsham, G. J., Rasmussen, T. B., Bøtner, A., Bødker, R. (2018b): Infection of pigs with African swine fever virus via ingestion of stable flies (Stomoxys calcitrans). - Transboundary Emerging Diseases 65: 1152-1157.

[29] Pejsak, Z., Piekut, J. (2018): Afrykański pomór świń - nowe doświadczenia w zwalczaniu choroby. - Platforma Edukacyjna Project System, Skierniewice, pp. 5-310.

[30] Pejsak, Z., Niemczuk, K., Frant, M., Mazur, M., Pomorska-Mól, M., Ziętek-Barszcz, A., Bocian, Ł., Łyjak, M., Borowska, D., Woźniakowski, G. (2018a): Four years of African swine fever in Poland. New insights into epidemiology and prognosis of future diseases spread. - Polish Journal Veterinary Sciences 21: 835-841. DOI: 10.24425/pjvs.2018.125598.

[31] Pejsak, Z., Romanowski, R., Niemczuk, K., Truszczyński, M. (2018b): Wild boar as the reservoir and source of transmission of African swine fever virus. - Życie Weterynaryjne 93: 224-227.

[32] Pejsak, Z., Truszczyński, M. (2017a): Biosecurity, the major way of protecting animals against infectious diseases. - Życie Weterynaryjne 92: 427-430.

[33] Pejsak, Z., Truszczyński, M. (2017b): Resistance of African swine virus to environmental conditions as well as physical and chemical factors. - Życie Weterynaryjne 92: 880-882.

[34] Pejsak, Z., Truszczyński, M. (2018): Herd health management founded on biosecurity and eradication of pathogenic agents. - Życie Weterynaryjne 93: 832-835.

[35] Pejsak, Z., Woźniakowski, G. (2017): The counteractions to the spread of African swine fever (ASF) with a special regard to the role of carcass disposal plants. - Życie Weterynaryjne 92: 804-807.

[36] Pejsak, Z., Truszczyński, M., Kozak, E., Markowska-Daniel, I. (2014a): Epidemiological analysis of the two first cases of African swine fever in wild boar in Poland. - Medycyna Weterynaryjna 70: 369-372. 
[37] Pejsak, Z., Truszczyński, M., Niemczuk, K., Kozak, E., Markowska-Daniel, I. (2014b): Epidemiology of African swine fever in Poland since the detection of the first case. Polish Journal Veterinary Science 17: 665-672.

[38] Plowright, W., Parker, J., Peirce, M. A. (1969): African swine fever virus in ticks (Ornithodoros moubata Murray) collected from animal burrows in Tanzania. - Nature 221: 1071-1073.

[39] Podgórski, T., Śmietanka, K. (2018): Do wild boar movements drive the spread of African Swine Fever? - Transboundary and Emerging Diseases 65: 1588-1596.

[40] Probst, C., Globig, A., Knol, B., Conraths, F. J., Depner, K. (2017): Behaviour of free ranging wild boar towards their dead fellows: potential implications for the transmission of African swine fever. - Royal Society Open Science 4: 170054.

[41] Schulz, K., Olševskis, E., Staubach, Ch., Lamberga, K., Seržants, M., Cvetkova, S., Conraths, F. J., Sauter-Luis, C. (2019a): Epidemiological evaluation of Latvian control measures for African swine fever in wild boar on the basis of surveillance data. Scientific Reports 9. doi.org/10.1038/s41598-019-40962-3.

[42] Schultz, K., Staubach, Ch., Blome, S., Viltrop, A., Nurmoja, I., Contraths, F. J., SauterLuis, C. (2019b): Analysis of Estonian surveillance in wild boar suggests a decline in the incidence of African swine fever. - Scientific Reports 9: 8490. doi.org/10.1038/s415980189-44890-0.

[43] Śmietanka, K., Woźniakowski, G., Kozak, E., Niemczuk, K., Frączyk, M., Bocian, Ł., Kowalczyk, A., Pejsak, Z. (2016): African swine fever epidemic, Poland, 2014-2015. Emerging Infectious Diseases 22: 1201-1207.

[44] Ståhl, K., Sternberg-Lewerin, S., Blome, S., Viltro, A., Penrith, M. L., Chenais, E. (2019): Lack of evidence for long term carriers of African swine fever virus - a systematic review. - Virus Research 272. doi.org/10.1016/j.virusres.2019.197725.

[45] Thomson, G. R. (1985): The epidemiology of African swine fever: the role of free-living hosts in Africa. - Onderstepoort Journal Veterinary Research 52: 201-209.

[46] Woźniakowski, G., Kozak, E., Kowalczyk, A., Łyjak, M., Pomolska-Mól, M., Niemczuk, K., Pejsak, Z. (2016): Current status of African swine fever virus in a population of wild boar in eastern Poland (2014-2015). - Archives Virology 161: 189-195.

[47] Vergne, T., Gogin, A., Pfeiffer, D. U. (2017): Statistical exploration of local transmission routes for African swine fever in pigs in the Russian Federation, 2007-2014. Transboundary Emerging Diseases 64: 504-512. DOI: 10.1111/tbed.12391. 